\title{
Sharing Economy and Government
}

\author{
Sounman Hong ${ }^{1, *}$ and Sanghyun Lee ${ }^{2}$ \\ 1 Department of Public Administration, Yonsei University, Seoul 03722, Korea \\ 2 Graduate School of Information, Yonsei University, Seoul 03722, Korea; leesanghyun@yonsei.ac.kr \\ * Correspondence: sounman_hong@yonsei.ac.kr
}

Received: 5 October 2020; Accepted: 27 November 2020; Published: 3 December 2020

\begin{abstract}
We compared sharing economy development in 90 countries to demonstrate that higher qualities of government are associated with greater sharing economy growth. To explain this finding, we assumed that sharing economy benefits are enjoyed by the public, whereas its costs are chiefly borne by market incumbents. In considering these competing interests, policymakers tend to favor the latter as single-industry interests that can be more easily organized to influence policymaking. We then hypothesized that an electorally competitive, depoliticized, and effective government may tilt the balance against the entrenched market incumbents, leading to the growth of sharing economy industries. Overall, we found some support for this hypothesis. We especially found that electoral competitiveness strongly impacted sharing economy development and that this impact was significantly greater in a country with a depoliticized bureaucracy and effective government.
\end{abstract}

Keywords: sharing economy; quality of government; electoral competitiveness; politicization; effective government

\section{Introduction}

Digital and information technologies have enabled the rise of the so-called "sharing economy", in which, through peer-to-peer activities, people grant each other temporary access to their underutilized assets for financial compensation [1-15]. This new industry's rapid growth and disruptive nature has initiated a fierce debate over the proper role of governments [8,16-18]. Proponents argue that governments should remove regulatory barriers for sharing economy firms, such as Airbnb or Uber, to improve economic efficiency, whereas critics call for stricter regulations to protect the rights of consumers, workers, and incumbent industries [19].

Governments around the globe have also adopted substantially different solutions in response to the rise of sharing economy. For example, the United States Conference of Mayors issued a resolution recommending "support for making cities more shareable." Despite such rhetoric, city governments have responded in a variety of ways to this new economy, with many cities announcing their intentions to ban popular sharing services such as Uber or Airbnb [12]. This heterogeneity in government responses is observed internationally as well. Unlike countries that welcome a sharing economy, such as Finland, Sweden, and Singapore, the South Korean government completely banned Uber, while Japan adopted strict regulations against short-term home-sharing services in 2018.

In this study, we asked why some governments around the world welcome the rise of the sharing economy, while others strongly oppose it. In order to contribute to this query, we hypothesized that higher quality government institutions would be associated with more favorable government policies for a sharing economy. We primarily focus on three aspects of institutional qualities: (1) electoral competitiveness, (2) depoliticized civil service, and (3) overall government effectiveness. Framing the rise of sharing economy as a battle between new entrants (e.g., Airbnb or Uber) and incumbent industries (e.g., taxi or hotels), we first explain why politicians have incentives to support 
the interests of market incumbents if their decisions are not held accountable. We then argue that higher quality governments, as measured by electoral competitiveness, depoliticized bureaucracy, and overall effectiveness, may weaken the established market incumbents' political power, leading to growth in sharing economy industries. We examine these arguments by demonstrating positive associations between the three institutional measures and the size of the sharing economy in a given country.

Our theoretical rationale is based on three different strands of literature. First, we regarded sharing services as typical examples of disruptive innovations, creating competition between sharing economy firms and market incumbents. Disruptive innovations generally incorporate new and unprecedented features, deviating so radically from existing alternatives that they destroy existing rules of competition [20,21]. Second, following Stigler's [22], we assume that the two economic interests (i.e., sharing economy firms and market incumbents) compete for political favor. Market incumbents seek to raise regulatory barriers to entry, while new entrants try to lower them. Third, we use the concept of "agile governance" or "adaptive governance" $[12,13,23]$ to explain why governments decide to raise or lower regulatory barriers to entry. We argue that governments suffer from "status quo bias," in which single-industry economic interests "capture" policymakers. However, if the political system possesses higher qualities, governments become more flexible, agile, and adaptive to environment changes and technological innovations, as they are held accountable for their decisions.

\section{Sharing Economy and the Roles of Government}

Previous literature on sharing economy and government may be grouped into several broad categories. The first set of literature examines the question of "who" benefits from the growth of sharing economy firms $[8,16,24-28]$. Overall, this group of studies focuses on sharing economy's "disruptive" nature [29]. These new business models repackage old technology to create new markets, disrupting the incumbent firms. Other studies have examined the cost-benefit distribution of sharing economy regulations [30]. For instance, some studies have explained that the benefits of sharing economy services are widely dispersed across the public, whereas their costs are concentrated on a relatively small number of incumbent firms $[12,13]$. Identifying the "winners" and "losers" from sharing economy growth provides the theoretical underpinnings for regulating this new innovation.

The second set of previous literature explores the question of "how" governments should regulate sharing economy firms [7,31-33]. In other words, this group of works explores regulatory issues related to the rapid growth of sharing economy industries. For instance, Edelman and Geradin [31] identified potential market failures associated with sharing economy businesses and proposed a regulatory framework that creates an efficient delivery of services while protecting service providers, consumers, and third parties. Similarly, Miller [33] offered a number of principles for regulating the sharing economy and proposed future options for governments to improve existing approaches to regulating the industry.

Lastly, a relatively small set of literature explains "why" some governments choose to heavily regulate sharing economy services, while others do not $[12,13,34]$. Some studies have applied the political economic perspective such as the capture theory to explain the varied response to this new industry, while others applied the adaptive governance framework. This latter group assumes that government responsiveness to the sharing economy may be analyzed from a more general framework of adaptive and agile governance [23]. This literature explores the political, economic, and social factors that may make governments flexible, agile, and adaptive to environment changes and technological innovations. This concept was applied to various government responses to the rise of sharing economy $[12,13]$.

This study contributes to this last strand of sharing economy research by making several theoretical and empirical advancements. Previous studies have clearly advanced our understanding of the sharing economy and governments' roles. To our knowledge, however, none of them have attempted to explain, from an international perspective, why sharing service industries have grown rapidly in some countries but not in others. Further, previous research has overlooked the possibility that, holding other economic 
factors constant, the institutional qualities of governments may have substantial impacts on digital innovation growth. This is an important omission in the literature, which limits our understanding of sharing economy growth and, more generally, crowd-based digital innovation. This current research addresses this paucity. In sum, this study contributes to the literature by presenting, at a multinational level, novel empirical evidence of the association between sharing economy growth and various institutional qualities of governments.

The remainder of the article proceeds as follows. In the next section, we explain our hypotheses. Then, we describe our methodology and explain how we constructed the dataset. In Section 5, we present the test of our proposed hypotheses. Based on the findings, we present the conclusion and discuss our findings in Section 6.

\section{Hypotheses}

\subsection{Politics of Sharing Economy Regulation}

Previous research on the politics of regulation attempted to explain who stands to gain or lose from government regulations, and what forms of regulation will be instituted, along with their welfare implications [22,35,36]. Wilson [30] presented a framework to understand the political significance of these economic stakes. In this framework, a regulation (or, more generally, a policy) is classified in terms of the perceived distribution of its benefits and costs. Specifically, both benefits and costs are either widely distributed across the public at large or narrowly concentrated on a definable segment of society (such as occupations, industries, or localities). This classification produces a two-by-two matrix, as shown in Figure 1.

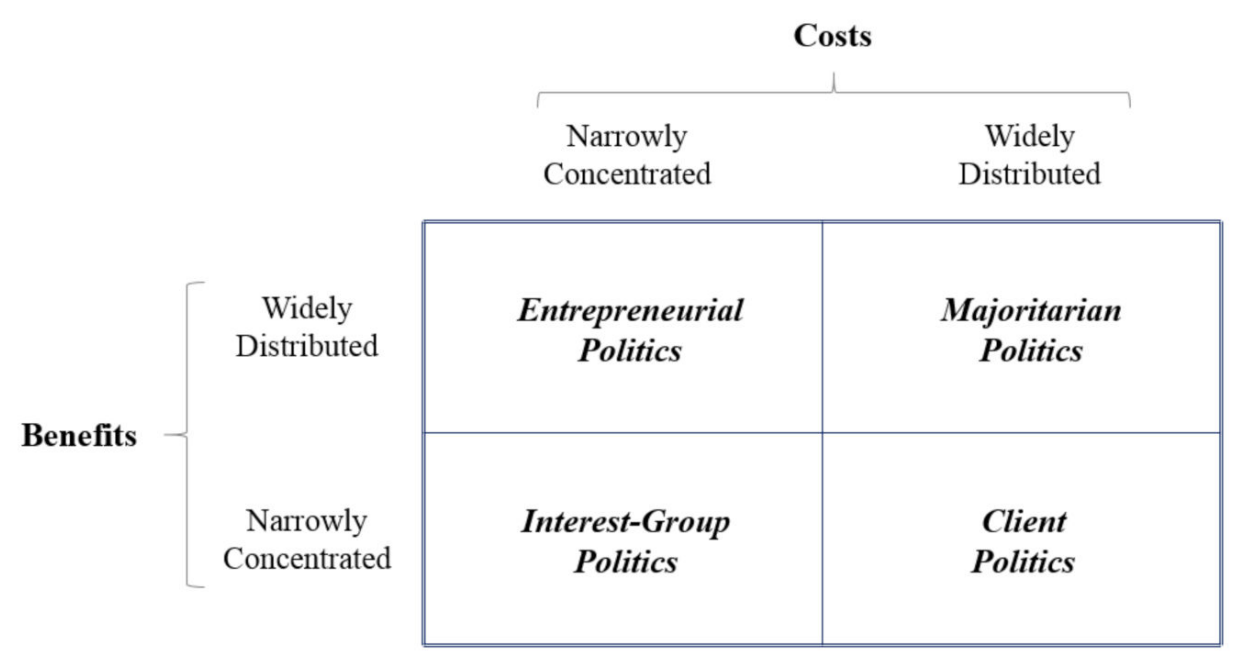

Figure 1. Cost-benefit distribution and four different types of policy situations.

The first quadrant of the matrix is where both benefits and costs are widely distributed across the public at large, a situation known as majoritarian politics. The opposite case is the so-called interest group politics, in which a policy's benefits and costs are all chiefly borne by a definable segment of citizens. In majoritarian politics, the public has little incentive to organize around common interests. On the other hand, in interest group politics, both groups have strong incentives to organize around common interests to influence policy decisions. We will not focus on these two situations in this study as they do not fit with the benefit-cost distribution of sharing economy regulations. Specifically, it would be incorrect to regard the sharing economy case as an interest group politics situation, as those individuals who stand to lose from entry barriers are those who would run sharing economy businesses if these barriers did not exist. In other words, the interest group politics case 
cannot adequately describe the benefit-cost distribution of an entry regulation for a new industry, as the group chiefly bearing the costs has not yet entered into the market and is thus not properly defined.

In analyzing the benefit-cost distribution of entry regulations for disruptive innovations, the other two situations are more useful. Client politics refers to a situation in which the costs of a policy or regulation are widely distributed across the public, while the benefits are enjoyed by a defined segment of society. Entrepreneurial politics presents an opposing situation; the benefits are dispersed, while the costs are concentrated. As Hong and Lee [12,13] demonstrated, the regulation of a sharing economy industry can be best described by either client politics or entrepreneurial politics. In fact, these two cases are like the two sides of a coin. Instituting entry regulation is a client politics situation, whereas removing it is an entrepreneurial politics situation. From an efficiency point of view, any regulations that slow down the growth of disruptive innovations will benefit the market incumbents, but reduce competition in the market, resulting in less competitive markets and higher prices for consumers. The market incumbents are the winners, whereas the consumers (and the early innovators such as Airbnb or Uber) are the losers. Most importantly, in the long run, such policies may even stifle the rate of market innovation and entrepreneurship.

In fact, previous scholars have paid special attention to entry regulations for disruptive innovations. Stigler [22] argued that regulation is acquired by the industry (in order to promote its own benefits), and the most typical form of "acquired regulation" is entry control. For instance, as Stigler [22] (p. 5) stated, "every industry or occupation that has enough political power to utilize the state will seek to control entry." As disruptive innovations emerge, the benefit-cost distribution of entry control follows the client politics situation. The benefits are enjoyed by the entrenched industries (e.g., taxi or hotels), while the costs are widely dispersed across potential consumers. In such cases, political science research has predicted that policymakers will serve the "client," with industrial economic interests carrying more weight in policy decisions than the public interest [37,38]. This is because "the [political] system is calculated to implement [ ... ] many strongly felt preferences of minorities but to disregard the lesser preferences of majorities" [22] (p. 12).

\subsection{Testable Hypotheses}

We thus far explained that, when disruptive innovations emerge, policymakers generally suffer from "status quo bias" (i.e., they design regulatory policies that slow the growth of new entrants). This phenomenon is described as "capture" in economics [39-41] and as "policy monopoly" in political science [38]. In this study, we propose that adaptive governance achieved by higher institutional qualities of governments may mitigate this bias. In the context of our case, we defined adaptive governance as a form of governance that advances public interests by overcoming "status quo bias" and accommodating disruptive innovations in the economy. Previous research has shown that decentralization makes governments more flexible, agile, and adaptive to environment changes [23,42] (but see [13]). As Janssen and Van der Voort [23] (p. 3) stated, the "core characteristics of adaptive governance [include] decentralized decision-making." In general, decentralization would make governments adaptive as it brings the government "closer to the people" in Montesquieu's sense. However, it is not clear whether this logic can apply to the case of sharing economy, because the benefits of the disruptive innovation are widely dispersed beyond local boundaries (e.g., see [13]).

Instead, we propose three institutional qualities of governments that may lead to adaptive governance: (1) electoral competitiveness, (2) depoliticized civil service, and (3) overall government effectiveness. From the standpoint of the public at large (who bears the costs of the regulations), elections are arguably the most effective institutional arrangements available for influencing public officials, as policymakers' fears of losing office in coming elections lead them to respond to citizen demands [43,44]. This institutional impact may be greater when politicians face competitive elections [12,45]. Therefore, it follows that more electoral competition will increase policymakers' responsiveness to citizen demands. This weakens the market incumbents' political power, which can lead to sharing economy growth. We thus present the following hypothesis: 
Hypothesis 1: A greater level of electoral competitiveness may be associated with greater sharing economy development.

Policymakers use regulations to favor organized interests, and thereby obtain campaign contributions and votes. This political incentive defies the rational process of cost-benefit analysis, and thus it would have a greater impact on policymaking when the civil service system is highly politicized. The notion that the neutral competence of bureaucracy would enhance public service performance can be traced back to earlier works, including Max Weber [46] and Woodrow Wilson [47]. Although a complete division between politics and administration is unrealistic, most scholars tend to agree that the politicization of civil service has negative impacts on public administration performance [48-51]. It therefore follows that a depoliticized civil service system that insulates itself from the political influence of organized interests will be less swayed by market incumbent voices, leading to sharing economy growth. We thus present the following hypothesis:

Hypothesis 2: Depoliticized civil service (i.e., a lower level of politicization in civil service) may be associated with greater sharing economy development.

Lastly, we also consider overall government effectiveness as a quality by which to measure governments. In this study, we follow Kaufmann et al. [52] to define overall government effectiveness as including the quality of the bureaucracy, the quality of public service provision, the competence of civil servants, the insulation of civil service from political influence, and the credibility of the government's commitment. Effective governments may also be more flexible, agile, and adaptive to environmental changes and technological innovations. It therefore follows that an effective government will be conducive to adaptive governance that considers public interest more heavily than the interests of market incumbents. We thus present the following hypothesis:

Hypothesis 3: A greater level of government effectiveness may be associated with greater sharing economy development.

As we will report in the results section, we found a robustly positive association between electoral competitiveness and the dependent variable, but failed to find comparably strong impacts from depoliticized civil service and overall government effectiveness. However, we argue that the impacts of these three institutional qualities complement one another. A greater level of electoral competitiveness makes policymakers more responsive to citizen demands as they fear losing office in the coming election. However, such impact would be smaller in a highly politicized civil service system, in which the organized interests of market incumbents have strong political influences. Similarly, the impact of greater electoral competitiveness would be smaller if the government is highly ineffective overall. In other words, even if the main effects of depoliticized civil service and overall government effectiveness were limited, these two institutional qualities could still play significant moderating roles as they greatly enhance the impact of electoral competitiveness on sharing economy development. We thus present the following hypotheses:

Hypothesis 4: The association between electoral competitiveness and sharing economy development may be greater in a country with a depoliticized civil service system.

Hypothesis 5: The association between electoral competitiveness and sharing economy development may be greater in a country with an effective government system. 


\section{Methods and Data}

\subsection{Method}

To evaluate the proposed hypotheses, we estimated the effects of three institutional qualities of governments on the development of sharing economy services. Among the many institutional characteristics, we chose (1) electoral competitiveness, (2) depoliticized civil service, and (3) overall government effectiveness as the treatment variables. The dependent variable was the nation-level development of sharing economy services, as measured by the global sharing economy index published by Timbro, a think tank based in Sweden. Specifically, the models used in this study are as follows:

$$
Y_{i}=\mu+\varrho \text { ElecComp }_{i}+\sigma \text { Depolit }_{i}+\tau \text { GovEffect }_{i}+X_{i} \gamma+\eta_{i}
$$

where $Y_{i}$ is this study's dependent variable, the sharing economy development in country $i$. This variable is constructed by compiling traffic volume and scraped data to estimate the overall development of the peer-to-peer economy [53]. The three treatment variables are (1) ElecComp $i$, the level of electoral

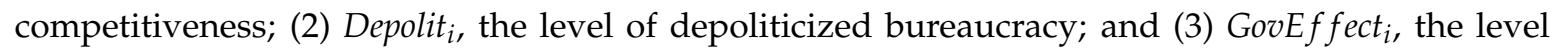
of overall government effectiveness of government in country $i$. The coefficients of interest are $\sigma$, and $\tau$, with $\eta_{i}$ as the error term. We used ordinary least squares (OLS) to estimate the impacts of the treatment variables.

We also included several control variables, $X_{i}$. First, we accounted for the potential differences in political systems by controlling for an indicator of a presidential system. Second, we controlled for the overall economy size, as measured by GDP per capita. We also included the country's degree of economic freedom, as measured by the economic freedom index from the Fraser Institute [54]; the regulatory environment conducive to business operation, as measured by the ease of doing business score from the World Bank; and the level of globalization, as measured by the globalization index [55]. Finally, the share of population using the Internet was also controlled for, as previous studies have cited infrastructure for information and communication technology as the most important determinant of sharing economy development [56].

\subsection{Data}

The primary challenge to the empirical investigation was the limited observations on the development of sharing economy services at country levels. We thus took advantage of the global sharing economy index recently published by Timbro, which measures the level of sharing economy usage in a country [53]. This variable combines online traffic and the number of active suppliers associated with the online peer-to-peer industry, producing a normalized per capita usage of a sharing economy. To our knowledge, this variable is the only measure that can compare sharing economy development across countries. We thus used this as our dependent variable.

The variables to the right were all drawn from several public sources. Electoral competitiveness measures, margin of minority, and the indicator of a presidential political system were all collected from the Database of Political Institutions 2017 (DPI 2017) compiled by the Development Research Group of the World Bank [57]. The level of depoliticized bureaucracy was collected from the QoG Expert Survey Data [58]. This variable was constructed by averaging the answers to survey items A, B, D, E, F, G, I, and J of Question 2, which we considered most relevant to a lower level of politicization. The level of government effectiveness was drawn from the Worldwide Governance Indicators compiled by the World Bank Group [52]. The size of the economy, as measured by GDP per capita, was taken from the Maddison Project Database [59]. The economic freedom index, ease of doing business score, and index of globalization were drawn, respectively, from the Economic Freedom of the World Database published by the Fraser Institute [54], ease of doing business report published by the World Bank Group [60], and the KOF index of globalization [61]. Finally, the share of individuals with Internet access as a percentage of the population was taken from the World Development Indicators compiled 
by the World Bank Group [62]. In Table 1, we present the summary statistics of all the variables included in this study.

Table 1. Summary statistics.

\begin{tabular}{cccccc}
\hline Variable & Obs. & Mean & Std. Dev. & Min & Max \\
\hline The development of sharing economy & 90 & 8.879 & 16.019 & 0 & 100 \\
Legislative electoral competitiveness & 90 & 6.667 & 1.049 & 1 & 7 \\
Executive electoral competitiveness & 90 & 6.522 & 1.265 & 1 & 7 \\
Margin of minority & 90 & 0.398 & 0.141 & 0 & 0.679 \\
Depoliticized bureaucracy & 90 & 4.539 & 0.443 & 3.017 & 5.427 \\
Government effectiveness & 90 & 0.287 & 0.925 & -1.298 & 2.237 \\
Presidential system & 90 & 0.456 & 0.501 & 0 & 1 \\
GDP per capita (in log) & 90 & 9.380 & 1.073 & 6.867 & 11.242 \\
Economic freedom & 90 & 63.724 & 9.357 & 37.6 & 89.4 \\
Ease of doing business & 90 & 65.113 & 11.575 & 43.22 & 91.71 \\
Globalization & 90 & 67.576 & 12.802 & 45.012 & 90.474 \\
Internet access & 90 & 53.672 & 26.278 & 4.174 & 98.2 \\
\hline
\end{tabular}

We note three issues regarding our data. First, the dependent variable of this study-the measured level of sharing economy usage in a country-was provided by a think tank that supports free markets. Some may be worried that the ideological position of this think tank may have introduced bias in the data. We strongly believe, however, that this potential measurement error was not critical. First, this think tank measured the level of sharing economy quantitatively, rather than qualitatively, by combining online traffic and the number of online peer-to-peer industry suppliers. Furthermore, the main goal of our analyses was to estimate not the level of sharing economy usage but the association between sharing economy usage and institutional qualities of the government. For the measurement error to bias our coefficients of interests, one should systematically over- or underestimate the level of sharing economy usage for countries with certain government qualities. Such a concern is not very likely to be realized, as there is no reason to believe that any researcher would introduce such systematic bias in the data, given the way this variable is constructed (i.e., quantitatively combining online traffic and the number of suppliers).

Second, we note that our sample size was 90; although the global sharing economy index was produced for 213 countries, we limited our analyses to the countries that have reliable data on the institutional qualities of government. As explained, the right-hand side variables, including the institutional qualities, were collected from various sources; the full set of variables were available only for the 90 countries, which constituted our final sample. We thus had no discretion over the inclusion of a particular country into the sample. Table 2 lists the 90 countries included for our analyses.

Third, the dependent variable, the global sharing economy, was constructed in 2018 on the basis of monthly-only traffic data and the number of active suppliers using automated "web scraping" techniques. Conversely, we used the most recently available data for the right-hand side variables. As these variables are generally not measured annually, the year each institutional characteristic was constructed differs across data sources. Such an issue is common in comparative analyses of government institutions. Furthermore, because of right-hand side variables not being measured annually, one may regard them as lagging by a year or two. 
Table 2. List of countries included in the analyses.

\begin{tabular}{|c|c|c|c|c|c|}
\hline Country & Index & Country & Index & Country & Index \\
\hline Iceland & 100 & Singapore & 5.6 & Senegal & 0.7 \\
\hline Malta & 58.2 & South Africa & 4.7 & Kazakhstan & 0.7 \\
\hline New Zealand & 52.8 & Fiji & 4 & Egypt & 0.6 \\
\hline Croatia & 52.2 & Brazil & 4 & Kyrgyzstan & 0.6 \\
\hline Denmark & 45.9 & Armenia & 3.7 & El Salvador & 0.6 \\
\hline Ireland & 41 & Germany & 3.4 & Ukraine & 0.6 \\
\hline Barbados & 29.4 & Sri Lanka & 3.4 & Indonesia & 0.6 \\
\hline Norway & 29 & Albania & 3.3 & Nepal & 0.5 \\
\hline Australia & 26.2 & Dominican Republic & 3 & Guyana & 0.5 \\
\hline Portugal & 25.6 & Mexico & 3 & Slovenia & 0.5 \\
\hline Spain & 22.7 & Argentina & 2.9 & Peru & 0.4 \\
\hline Greece & 22.5 & Morocco & 2.5 & Colombia & 0.3 \\
\hline Italy & 21.2 & Thailand & 2.4 & China & 0.3 \\
\hline Georgia & 20.3 & Romania & 2.4 & Zimbabwe & 0.3 \\
\hline Canada & 16.6 & Japan & 1.9 & Ghana & 0.3 \\
\hline Switzerland & 16 & Nicaragua & 1.8 & Rwanda & 0.2 \\
\hline Netherlands & 14.6 & Poland & 1.8 & Algeria & 0.2 \\
\hline Estonia & 14 & Turkey & 1.8 & Uganda & 0.2 \\
\hline Sweden & 13.4 & Ecuador & 1.8 & Mozambique & 0.1 \\
\hline Israel & 13.1 & Lebanon & 1.4 & Togo & 0.1 \\
\hline Finland & 12.5 & Philippines & 1.3 & Madagascar & 0.1 \\
\hline Uruguay & 11.7 & Lithuania & 1.2 & India & 0.1 \\
\hline Mauritius & 11.3 & Kenya & 1.2 & Cameroon & 0.1 \\
\hline Chile & 9.8 & Guatemala & 1.1 & Benin & 0.1 \\
\hline Belgium & 9.4 & Botswana & 1 & Tajikistan & 0.1 \\
\hline Jamaica & 6.9 & Austria & 0.9 & Slovakia & 0.1 \\
\hline Latvia & 6.9 & Cambodia & 0.9 & Malawi & 0.1 \\
\hline Hungary & 6.5 & Vietnam & 0.8 & Nigeria & 0 \\
\hline Bulgaria & 6.1 & Azerbaijan & 0.7 & Guinea & 0 \\
\hline Bosnia & 5.7 & Costa Rica & 0.7 & Bangladesh & 0 \\
\hline
\end{tabular}

\section{Results}

\subsection{Main Impacts of Government Qualities}

Before we present the results of our regression analysis, we first present descriptive figures that visually depict the associations between the dependent and treatment variables. In Figure 2, we show the association between sharing economy development in a country and electoral competitiveness. The key variable of our interest, electoral competitiveness, measures how much competition political actors who occupy the legislative and executive branches face in elections. This variable is measured separately for each branch. In Figure 2a, we show the association between sharing economy development and legislative electoral competitiveness, whereas in Figure $2 b$ we have executive electoral competitiveness. As observed, we found a positive association between the two treatments and dependent variable. Overall, a greater level of electoral competitiveness in either the legislative or the executive branch was associated with greater sharing economy development.

In Figure 2c,d we discuss the second and third hypotheses. In Figure 2c, we show the association between sharing economy development in a country and depoliticized civil service (i.e., a lower level of politicization). Here, the figure fails to show a clear positive or a clear negative association between the two variables; thus, the second hypothesis is not strongly supported in the figure. On the other hand, in Figure $2 \mathrm{~d}$ we explore the third hypothesis by examining the association between sharing economy development and government effectiveness. Overall, the figure shows a clear association between the two variables, supporting the third hypothesis: a greater level of government effectiveness is associated with greater sharing economy development. 


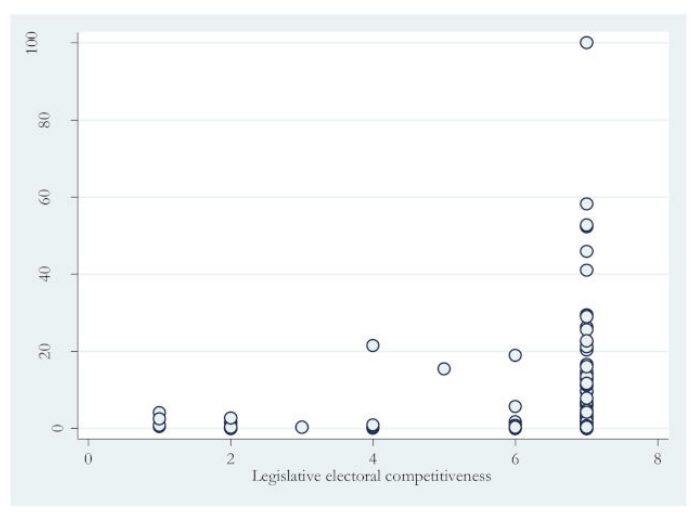

(a)

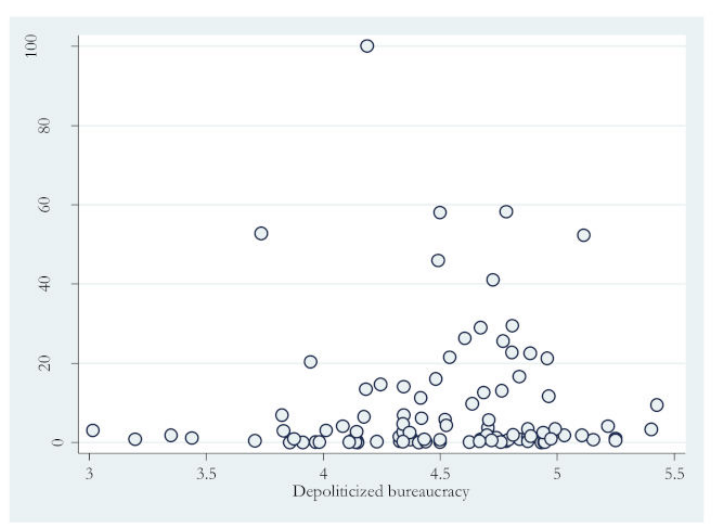

(c)

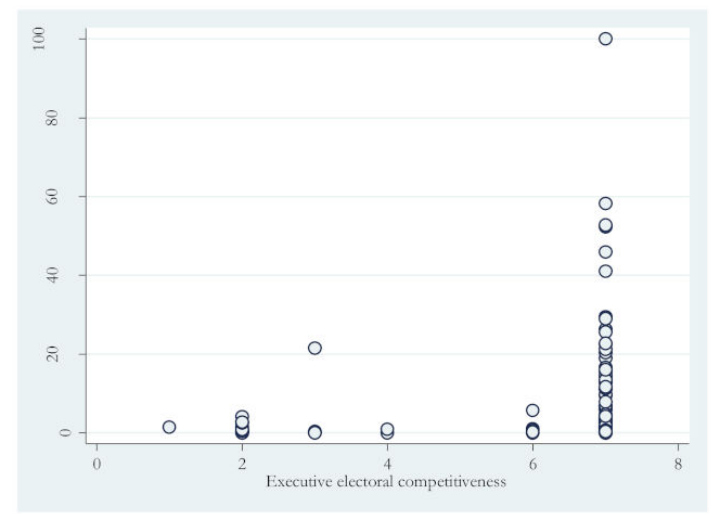

(b)

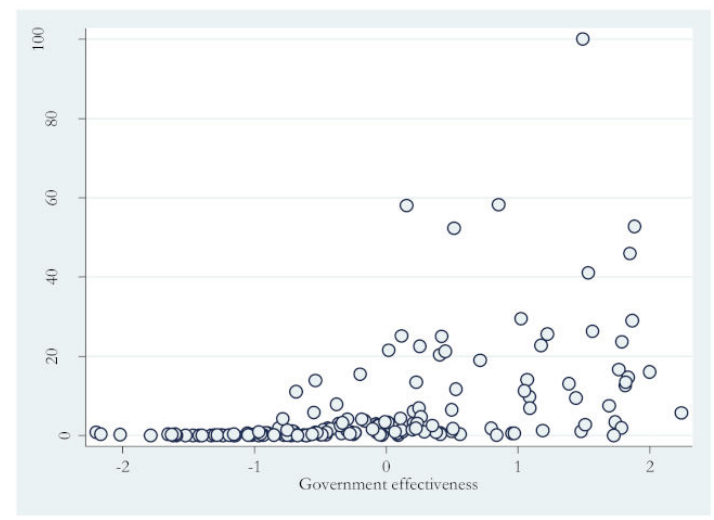

(d)

Figure 2. Associations between government qualities and sharing economy. (a) sharing economy development and legislative electoral competitiveness; (b) sharing economy development and executive electoral competitiveness; (c) sharing economy development and depoliticized bureaucracy; (d) sharing economy development and government effectiveness.

We evaluated the robustness of the results from the graphical analyses in Figure 2 by estimating the regression model with control variables. The regression results are reported in Table 3 . In column 1 of Table 3, we have legislative electoral competitiveness, while in column 2 we include executive electoral competitiveness. We did not test the impacts of the two variables (i.e., legislative and executive electoral competitiveness) in a single model, as both were highly correlated with each other. In column 1 of Table 3, we report that legislative electoral competitiveness and overall government effectiveness were both positively associated with sharing economy development, whereas in column 2 we find that only executive electoral competitiveness was positively associated with it. We found no evidence that the level to which the civil service system is politicized impacted sharing economy usage in the country. We also found little evidence that an indicator of economic freedom was a significant predictor for the size of the sharing economy (see Table 3).

OLS regression results showed a clearly positive impact of electoral competitiveness on the development of a sharing economy. To check robustness, we tested our hypotheses by replacing the electoral competitiveness variable with an alternative measure. Specifically, we included a margin of minority, which is the fraction of seats not held by the government (i.e., held either by opposition or by nonaligned parties). As we hypothesized that policymakers' fears of losing office in upcoming elections was the very force that drives them to respond to citizen demands, we posited that both electoral competitiveness and the margin of minority would have identical impacts on policymakers' behavior. We demonstrate the result in column 3 of Table 3. We report that the margin of minority and overall government effectiveness were both positively associated with sharing economy development. 
Table 3. Sharing economy development and qualities of government (Hypotheses 1-3).

\begin{tabular}{cccc}
\hline & \multicolumn{3}{c}{ Dependent Variable: } \\
& Sharing Economy Development \\
\cline { 2 - 4 } & $\mathbf{( 1 )}$ & $\mathbf{( 2 )}$ & $\mathbf{( 3 )}$ \\
\hline Legislative electoral competitiveness & $2.112^{* *}$ & & \\
& $(0.990)$ & & \\
Executive electoral competitiveness & & $2.226^{* *}$ & \\
Margin of minority & & $(1.025)$ & $19.08^{* *}$ \\
& & & $(7.593)$ \\
Depoliticized bureaucracy & -3.266 & -3.363 & -2.720 \\
& $(3.085)$ & $(3.168)$ & $(2.985)$ \\
Government effectiveness & $5.336^{*}$ & 3.494 & $7.165 * *$ \\
& $(3.157)$ & $(2.698)$ & $(3.374)$ \\
Presidential system & $-6.672 * *$ & $-7.038^{* *}$ & $-6.480 *$ \\
GDP per capita (in log) & $(2.809)$ & $(2.805)$ & $(2.707)$ \\
& -2.497 & -2.877 & -2.067 \\
Economic freedom & $(2.356)$ & $(2.332)$ & $(2.296)$ \\
& -0.170 & -0.093 & -0.093 \\
Ease of doing business & $(0.252)$ & $(0.240)$ & $(0.225)$ \\
Globalization & 0.210 & 0.195 & 0.065 \\
& $(0.341)$ & $(0.330)$ & $(0.307)$ \\
Internet access & -0.336 & -0.364 & -0.430 \\
& $(0.447)$ & $(0.448)$ & $(0.457)$ \\
$N$ & 0.290 & $0.358^{*}$ & 0.295 \\
$R^{2}$ & $(0.183)$ & $(0.196)$ & $(0.183)$ \\
\hline \multirow{2}{*}{$N$} & 90 & 90 & 90 \\
& 0.351 & 0.362 & 0.358 \\
\hline & &
\end{tabular}

Note: Standard errors in parentheses, ${ }^{*} p<0.10,{ }^{* *} p<0.05$.

\subsection{Moderating Impacts of Government Qualities}

We thus far have demonstrated that some institutional qualities of governments may have strong impacts on the development of the country's sharing economy. Among the three institutional characteristics of government, we found robust and strong evidence that electoral competitiveness impacts both legislative or executive branches. The other two measures (i.e., a lower level of politicization and overall government effectiveness) were not clearly associated with the dependent variable. However, as we presented in Hypotheses 4 and 5, the positive impacts of the three institutional qualities may complement one another. In particular, the impact of electoral competitiveness may be greater in a system with an effective and depoliticized government.

Tables 4 and 5 report the results of the regressions that test Hypotheses 4 and 5. In Table 4, we estimated the moderating role of depoliticized civil service. In Table 3, we failed to find that a lower level of politicization has a positive impact on sharing economy development. This finding was unexpected, given that previous studies have consistently reported the negative consequences of a politicized political system $[48,49,63]$. However, if we focus on the moderating role of depoliticized bureaucracy as is reported in Table 4, we clearly find that a lower level of politicization contributed to the country's development of sharing economy services. The same conclusion holds for the overall government effectiveness, as we report in Table 5 . Our results may be summarized as follows: a greater level of electoral competitiveness (in either the legislative or the executive branch) is associated with greater sharing economy development, and this association becomes greater when the country has depoliticized civil service and effective government systems. 
Table 4. Sharing economy development and qualities of government (Hypothesis 4).

\begin{tabular}{|c|c|c|c|}
\hline & \multicolumn{3}{|c|}{$\begin{array}{l}\text { Dependent Variable: } \\
\text { Sharing Economy Development }\end{array}$} \\
\hline & (1) & (2) & (3) \\
\hline Legislative electoral competitiveness & $\begin{array}{c}2.585^{* *} \\
(1.037)\end{array}$ & & \\
\hline Legislative electoral competitiveness $\times$ Depoliticized bureaucracy & $\begin{array}{l}2.863 \text { * } \\
(1.492)\end{array}$ & & \\
\hline Executive electoral competitiveness & & $\begin{array}{c}3.026^{* *} \\
(1.110)\end{array}$ & \\
\hline Executive electoral competitiveness $\times$ Depoliticized bureaucracy & & $\begin{array}{l}4.667^{* *} \\
(2.314)\end{array}$ & \\
\hline Margin of minority & & & $\begin{array}{l}20.03^{* *} \\
(7.371)\end{array}$ \\
\hline Margin of minority $\times$ Depoliticized bureaucracy & & & $\begin{array}{l}40.60^{* *} \\
(19.21)\end{array}$ \\
\hline Depoliticized bureaucracy & $\begin{array}{l}-3.956 \\
(3.042)\end{array}$ & $\begin{array}{l}-4.998 \\
(3.299)\end{array}$ & $\begin{array}{l}-4.205 \\
(3.202)\end{array}$ \\
\hline Government effectiveness & $\begin{array}{l}5.895 * \\
(3.232)\end{array}$ & $\begin{array}{c}4.333 \\
(2.754) \\
\end{array}$ & $\begin{array}{l}7.547^{* * *} \\
(3.416)\end{array}$ \\
\hline$N$ & 90 & 90 & 90 \\
\hline$R^{2}$ & 0.354 & 0.370 & 0.374 \\
\hline
\end{tabular}

Note: Standard errors in parentheses, ${ }^{*} p<0.10,{ }^{* *} p<0.05$; each model controls for the following variables: an indicator of presidential system, GDP per capita, economic freedom index, ease of doing business score, index of globalization, and the share of individuals with Internet access in the country. 
Table 5. Sharing economy development and qualities of government (Hypothesis 5).

\begin{tabular}{|c|c|c|c|}
\hline & \multicolumn{3}{|c|}{$\begin{array}{l}\text { Dependent Variable: } \\
\text { Sharing Economy Development }\end{array}$} \\
\hline & (1) & (2) & (3) \\
\hline Legislative electoral competitiveness & $\begin{array}{c}2.908^{* *} \\
(1.348)\end{array}$ & & \\
\hline Legislative electoral competitiveness $\times$ Government Effectiveness & $\begin{array}{l}3.572 \text { * } \\
(1.828)\end{array}$ & & \\
\hline Executive electoral competitiveness & & $\begin{array}{c}3.649^{* *} \\
(1.467)\end{array}$ & \\
\hline Executive electoral competitiveness $\times$ Government Effectiveness & & $\begin{array}{c}3.060^{* *} \\
(1.353)\end{array}$ & \\
\hline Margin of minority & & & $\begin{array}{l}20.85^{* *} \\
(7.411)\end{array}$ \\
\hline Margin of minority $\times$ Government Effectiveness & & & $\begin{array}{l}13.35^{*} \\
(7.898)\end{array}$ \\
\hline Depoliticized bureaucracy & $\begin{array}{l}-3.138 \\
(3.043)\end{array}$ & $\begin{array}{l}-2.968 \\
(3.101)\end{array}$ & $\begin{array}{l}-2.441 \\
(2.931)\end{array}$ \\
\hline Government effectiveness & $\begin{array}{c}4.769 \\
(2.955) \\
\end{array}$ & $\begin{array}{l}3.686 \\
(2.711) \\
\end{array}$ & $\begin{array}{l}6.774^{* *} \\
(3.302)\end{array}$ \\
\hline$N$ & 90 & 90 & 90 \\
\hline$R^{2}$ & 0.376 & 0.360 & 0.368 \\
\hline
\end{tabular}

Note: Standard errors in parentheses, ${ }^{*} p<0.10,{ }^{* *} p<0.05$; each model controls for the following variables: an indicator of presidential system, GDP per capita, economic freedom index, ease of doing business score, index of globalization, and the share of individuals with Internet access in the country. 


\section{Discussion and Conclusions}

As the Nobel-prize winning economist Michael Spence stated, "the Internet-led process of exploiting under-utilized resources-be they physical and financial capital or human capital and talent-is both unstoppable and accelerating" [64]. The number of rooms available on the online home-rental service, Airbnb, has already surpassed the world's largest hotel chains [65]. However, the development of sharing economy services has not been uniform across the globe [66-71]. Sharing economy industries already represent a sizable share of the total economy in some countries, but not in others. This study argues that some institutional characteristics of governments can significantly explain the variations in sharing economy development across countries. Specifically, we considered the following three characteristics: (1) electoral competitiveness, (2) depoliticized civil service, and (3) overall government effectiveness. These institutional qualities may explain, at least in part, why some governments try to ban, prohibit, or inhibit this innovation's growth, while others try to promote it.

To explain the governments' roles, we first focused on sharing economy's disruptive nature, framing its growth as a battle between new entrants (e.g., Airbnb or Uber) and market incumbents (e.g., taxi or hotels). We then explained why policymakers have incentives to protect the market incumbents. The benefits of sharing economy growth are widely dispersed across the public, whereas its costs are chiefly borne by the incumbents. This "client politics" situation leads market incumbents to organize around common interests to influence policy decisions, and policymakers are often "captured" by private interest groups. We then hypothesized that an electorally competitive, depoliticized, and effective government may tilt the balance against the established market incumbents, leading to the growth of sharing economy industries.

In comparing sharing economy development in 90 countries, we found broad support for the hypothesis that a country's institutional qualities of government are significantly associated with sharing economy usage in the country. Specifically, we showed that electoral competitiveness has an especially strong impact on both the legislative and executive branches with regard to sharing economy development. In an electorally competitive political system, policymakers may fear losing office in upcoming elections. This electoral accountability leads policymakers to respond to public interest over market incumbents' interests. While we did not find that either depoliticized or effective governments have an equally significant impact alone, we did find that these characteristics strengthen the impact of electoral competitiveness. In sum, we demonstrated that a country's institutional qualities of government are important determinants in sharing economy development, even after we control for a variety of key economic variables, including economy size, globalization, economic freedom, ease of doing business, and Internet access.

Our findings provide important implications for the governments' role in promoting sharing economy and, more broadly, open innovation. Sharing economy allows entrepreneurs to leverage the resources of the public, while open innovation enables them to develop creative ideas, products, and services with the public. Together, these new concepts may be combined to promote innovation and revolution across industries. Our findings may indicate that governments can also play an important role in the process by influencing either the culture or engineering of innovation [70]. This argument is also consistent with prior research in the quadruple helix model, which recognizes the roles of four major actors (i.e., science, industry, society, and policy) in the innovation system [71,72]. Recent literature in the quadruple helix model shows that governments play a critical role in involving the public in innovation processes [73].

Before we conclude, we note several issues regarding our analyses. First, we are cautious in drawing a decisive conclusion from our results, as we relied on cross-sectional observations. We concede that the coefficients we reported may not necessarily represent a causal impact of the institutional qualities. Second, as we explained, the dependent variable of this study was provided by a think tank that supports free markets, which may have introduced bias in the data. We believe that the potential measurement error was not a critical issue, as the variable is constructed quantitatively rather than 
qualitatively and there is no reason to expect that the size of the error is correlated with the institutional qualities of governments. We still acknowledge that our findings may become more compelling if supported by future research with alternative datasets. Third, we generally assumed that the growth of sharing economy industries benefits society. However, this normative assumption is not critical in the interpretation of our findings. It is possible that the sharing economy's widely dispersed benefits enjoyed by the public may not outweigh its losses incurred by the market incumbents; in this situation, introducing a sharing economy could be detrimental to society. Even in such a case, assuming that policymakers consider these competing interests, we can still argue that the three institutional qualities of government may lead policymakers to weigh public interest more heavily than the interests of market incumbents. Our data provided empirical support for this hypothesis. Previous research has shown that, with a higher quality of government, a country can reap the benefits of economic and social developments $[74,75]$. This study's findings suggest that this general proposition may apply to sharing economy development and, more generally, crowd-based capitalism.

Author Contributions: Conceptualization \& methodology, S.H. and S.L.; writing—original draft preparation, S.H.; writing - review and editing, S.L.; project administration, S.H. and S.L. Both authors have read and agreed to the published version of the manuscript.

Funding: This research received no external funding.

Conflicts of Interest: The authors declare no conflict of interest.

\section{References}

1. Barbe, A.S.; Hussler, C. “The war of the worlds won't occur": Decentralized evaluation systems and orders of worth in market organizations of the sharing economy. Technol. Forecast. Soc. Chang. 2019, 143, 64-75. [CrossRef]

2. Chen, C.C.; Chang, Y.C. What drives purchase intention on Airbnb? Perspectives of consumer reviews, information quality, and media richness. Telemat. Inform. 2018, 35, 1512-1523. [CrossRef]

3. Cannon, S.; Summers, L.H. How Uber and the sharing economy can win over regulators. Harv. Bus. Rev. 2014, 13, 24-28.

4. Davlembayeva, D.; Papagiannidis, S.; Alamanos, E. Sharing economy: Studying the social and psychological factors and the outcomes of social exchange. Technol. Forecast. Soc. Chang. 2020, 158, 120143. [CrossRef]

5. Dabbous, A.; Tarhini, A. Assessing the impact of knowledge and perceived economic benefits on sustainable consumption through the sharing economy: A sociotechnical approach. Technol. Forecast. Soc. Chang. 2019, 149, 119775. [CrossRef]

6. Sundararajan, A. From Zipcar to the sharing economy. Harv. Bus. Rev. 2013, 1, 1-2.

7. Sundararajan, A. The Sharing Economy: The End of Employment and the Rise of Crowd-Based Capitalism; MIT Press: Cambridge, MA, USA, 2016.

8. Martin, C.J. The sharing economy: A pathway to sustainability or a nightmarish form of neoliberal capitalism? Ecol. Econ. 2016, 121, 149-159. [CrossRef]

9. Nadeem, W.; Juntunen, M.; Shirazi, F.; Hajli, N. Consumers' value co-creation in sharing economy: The role of social support, consumers' ethical perceptions and relationship quality. Technol. Forecast. Soc. Chang. 2020, 151, 119786. [CrossRef]

10. Califf, C.B.; Brooks, S.; Longstreet, P. Human-like and system-like trust in the sharing economy: The role of context and humanness. Technol. Forecast. Soc. Chang. 2020, 154, 119968. [CrossRef]

11. Geissinger, A.; Laurell, C.; Sandström, C. Digital Disruption beyond Uber and Airbnb-Tracking the long tail of the sharing economy. Technol. Forecast. Soc. Chang. 2020, 155, 119323. [CrossRef]

12. Hong, S.; Lee, S. Adaptive governance, status quo bias, and political competition: Why the sharing economy is welcome in some cities but not in others. Gov. Inform. Q. 2018, 35, 283-290. [CrossRef]

13. Hong, S.; Lee, S. Adaptive governance and decentralization: Evidence from regulation of the sharing economy in multi-level governance. Gov. Inform. Q. 2018, 35, 299-305. [CrossRef]

14. Hong, S.; Ryu, J. The Role of Government in Crowdfunding for Achieving Co-Funding of Public Projects. In Proceedings of the 19th Annual International Conference on Digital Government Research: Governance in the Data Age, Delft, The Netherlands, 30 May-1 June 2018; pp. 1-6. 
15. Hong, S.; Ryu, J. Crowdfunding public projects: Collaborative governance for achieving citizen co-funding of public goods. Gov. Inform. Q. 2019, 36, 145-153. [CrossRef]

16. Morozov, E. The ‘Sharing Economy' Undermines Workers Rights. 2013. Available online: http://evgenymorozov. tumblr.com/post/64038831400/the-sharing-economyundermines-workers-rights (accessed on 8 January 2017).

17. Murillo, D.; Buckland, H.; Val, E. When the sharing economy becomes neoliberalism on steroids: Unravelling the controversies. Technol. Forecast. Soc. Chang. 2017, 125, 66-76. [CrossRef]

18. Schor, J. Debating the sharing economy. J. Self Gov. Manag. Econ. 2016, 4, 7-22.

19. Baker, D. Don't Buy the 'Sharing Economy' Hype: Airbnb and Uber Are Facilitating RipOffs. 2014. Available online: http://www.theguardian.com/commentisfree/2014/may/27/airbnb-uber-taxes-regulation (accessed on 3 March 2019).

20. Lyytinen, K.; Rose, G.M. The disruptive nature of information technology innovations: The case of internet computing in systems development organizations. MIS Q. 2003, 27, 557-596. [CrossRef]

21. Christensen, C.M.; Bower, J.L. Customer power, strategic investment, and the failure of leading firms. Strateg. Manag. J. 1996, 17, 197-218. [CrossRef]

22. Stigler, G.J. The theory of economic regulation. Bell J. Econ. Manag. Sci. 1971, 2, 3-21. [CrossRef]

23. Janssen, M.; Van der Voort, H. Adaptive governance: Towards a stable, accountable and responsive government. Gov. Inform. Q. 2016, 33, 1-5. [CrossRef]

24. Avital, M.; Andersson, M.; Nickerson, J.; Sundararajan, A.; Van Alstyne, M.; Verhoeven, D. The Collaborative Economy: A Disruptive Innovation or Much Ado About Nothing? In Proceedings of the 35th International Conference on Information Systems, Bangkok, Thailand, 13-16 January 2014; pp. 1-7.

25. Guttentag, D. Airbnb: Disruptive innovation and the rise of an informal tourism accommodation sector. Curr. Issues Tour. 2015, 18, 1192-1217. [CrossRef]

26. Hamari, J.; Sjöklint, M.; Ukkonen, A. The sharing economy: Why people participate in collaborative consumption. J. Assoc. Inform. Sci. Technol. 2016, 67, 2047-2059. [CrossRef]

27. Quattrone, G.; Proserpio, D.; Quercia, D.; Capra, L.; Musolesi, M. Who Benefits From the Sharing Economy of Airbnb? In Proceedings of the 25th International Conference on World Wide Web, Montreal, QC, Canada, 11-15 April 2016; pp. 1385-1394.

28. Benjaafar, S.; Kong, G.; Li, X.; Courcoubetis, C. Peer-to-peer product sharing: Implications for ownership, usage, and social welfare in the sharing economy. Manag. Sci. 2019, 65, 477-493. [CrossRef]

29. Christensen, C.M. The Innovator's Dilemma: When New Technologies Cause Great Firms to Fail; Harvard Business School Press: Boston, MA, USA, 2018.

30. Wilson, J.Q. The Politics of Regulation; Basic Books, Inc.: New York, NY, USA, 1980.

31. Edelman, B.G.; Geradin, D. Efficiencies and regulatory shortcuts: How should we regulate companies like Airbnb and Uber. Stanf. Techol. Law Rev. 2015, 19, 293-328. [CrossRef]

32. Katz, V. Regulating the sharing economy. Berkeley Technol. Law J. 2015, 30, 1067-1126.

33. Miller, S.R. First principles for regulating the sharing economy. Harv. J. Legis. 2016, 53, 147-202. [CrossRef]

34. Koopman, C.; Mitchell, M.; Thierer, A. The sharing economy and consumer protection regulation: The case for policy change. J. Bus. Entrep. Law 2014, 8, 529-546. [CrossRef]

35. Peltzman, S. Toward a more general theory of regulation. J. Law Econ. 1976, 19, 211-240. [CrossRef]

36. Carrigan, C.; Coglianese, C. The politics of regulation: From new institutionalism to new governance. Annu. Rev. Political Sci. 2011, 14, 107-129. [CrossRef]

37. Schattschneider, E.E. The Semi-Sovereign People; Holt, Rinehart and Winston: New York, NY, USA, 1960.

38. Baumgartner, F.R.; Jones, B.D. Agendas and Instability in American Politics; University of Chicago Press: Chicago, IL, USA, 2010.

39. Laffont, J.J.; Tirole, J. The politics of government decision-making: A theory of regulatory capture. Q. J. Econ. 1991, 106, 1089-1127. [CrossRef]

40. Hong, S.; Lim, J. Capture and the bureaucratic mafia: Does the revolving door erode bureaucratic integrity? Public Choice 2016, 166, 69-86. [CrossRef]

41. Hong, S.; Kim, T.K. Regulatory capture in agency performance evaluation: Industry expertise versus revolving-door lobbying. Public Choice 2017, 171, 167-186. [CrossRef]

42. Brunner, R.D.; Lynch, A.H. Adaptive Governance and Climate Change; Springer: Berlin/Heidelberg, Germany, 2010.

43. Adsera, A.; Boix, C.; Payne, M. Are you being served? Political accountability and quality of government. J. Law Econ. Organ. 2003, 19, 445-490. [CrossRef] 
44. Hong, S. What are the areas of competence for central and local governments? Accountability mechanisms in multi-level governance. J. Public Adm. Res. Theory 2017, 27, 120-134. [CrossRef]

45. Hong, S.; Kim, S.H.; Son, J. Bounded rationality, blame avoidance, and political accountability: How performance information influences management quality. Public Manag. Rev. 2020, 22, 1240-1263. [CrossRef]

46. Weber, M. Economy and Society; University of California Press: Berkeley, CA, USA, 1998.

47. Wilson, W. The study of administration. Political Sci. Q. 1887, 2, 197-222. [CrossRef]

48. Peters, B.G.; Pierre, J. Politicization of the Civil Service: Concepts, Causes, Consequences. In Politicization of the Civil Service in Comparative Perspective; Peters, B.G., Pierre, J., Eds.; Routledge: London, UK, 2004; pp. 1-13.

49. Dahlström, C.; Niklasson, B. The politics of politicization in Sweden. Public Adm. 2013, 91, 891-907. [CrossRef]

50. Hong, S.; Kim, Y. Loyalty or Competence: Political Use of Performance Information and Negativity Bias. Public Adm. Rev. 2019, 79, 829-840. [CrossRef]

51. Kim, B.H.; Hong, S. Political change and turnovers: How do political principals consider organizational, individual, and performance information? Public Choice 2019, 181, 291-308. [CrossRef]

52. Kaufmann, D.; Kraay, A.; Mastruzzi, M. The worldwide governance indicators: Methodology and analytical issues. Hague J. Rule Law 2011, 3, 220-246. [CrossRef]

53. Bergh, A.; Funcke, A.; Wernberg, J. Timbro Sharing Economy Index; TIMBRO: Stockholm, Sweden, 2018.

54. Gwartney, J.; Lawson, R.; Hall, J. Economic Freedom Dataset 2016. Fraser Institute. Available online: https://www.fraserinstitute.org/economic-freedom/dataset (accessed on 23 July 2019).

55. Dreher, A. Does globalization affect growth? Evidence from a new index of globalization. Appl. Econ. 2006, 38, 1091-1110. [CrossRef]

56. Bergh, A.; Funcke, A. Does Country Level Social Trust Predict the Size of the Sharing Economy? IFN Working Paper No. 1130; IFN: Stockholm, Sweden, 2016.

57. Cruz, C.; Keefer, P.; Scartascini, C. Database of Political Institutions 2017 (DPI2017), Inter-American Development Bank, Numbers for Development. Available online: https://mydata.iadb.org/ReformModernization-of-the-State/Database-of-Political-Institutions-2017/938i-s2bw (accessed on 22 July 2019).

58. Dahlström, C.; Teorell, J.; Dahlberg, S.; Hartmann, F.; Lindberg, A.; Nistotskaya, M. The QoG Expert Survey Dataset II; University of Gothenburg: Stockholm, Sweden, 2015.

59. Bolt, J.; Inklaar, R.; de Jong, H.; van Zanden, J.L. Maddison Project Database. 2018. Available online: https://www.rug.nl/ggdc/historicaldevelopment/maddison/research (accessed on 21 July 2019).

60. World Bank Group. Doing Business Data 2018. Available online: http://www.doingbusiness.org/en/data (accessed on 3 July 2019).

61. Gygli, S.; Haelg, F.; Sturm, J.-E. The KOF Globalization Index-Revisited; KOF Working Papers, No. 439; KOF Swiss Economic Institute, ETH Zurich: Zurich, Switzerland, 2018. [CrossRef]

62. World Bank. World Development Indicators; World Bank: Washington, DC, USA, 2016.

63. Rouban, L. Politicization of the Civil Service. In Handbook of Public Administration; Pierre, B.G.P.J., Ed.; Sage Publications: London, UK, 2005; pp. 310-320.

64. Spence, M. The Inexorable Logic of the Sharing Economy. Project Syndicate. 2015. Available online: https:// www.project-syndicate.org/commentary/inexorable-logic-sharing-economy-by-michael-spence-2015-09? barrier=accesspaylog (accessed on 7 March 2019).

65. McDermid, R. Airbnb's Number of Listings Surpasses Rooms Held by Top 5 Hotel Brands Combined. Available online: https:/www.bizjournals.com/sanfrancisco/news/2017/08/11/airbnb-surpasses-ihg-wynhilton-marriott-listings.html (accessed on 7 March 2019).

66. Liu, Z.; Ma, L.; Huang, T.; Tang, H. Collaborative Governance for Responsible Innovation in the Context of Sharing Economy: Studies on the Shared Bicycle Sector in China. J. Open Innov. Technol. Mark. Complex. 2020, 6, 35. [CrossRef]

67. Kim, Y.; Lee, M. Typology and Unified Model of the Sharing Economy in Open Innovation Dynamics. J. Open Innov. Technol. Mark. Complex. 2019, 5, 102. [CrossRef]

68. Liu, Z.; Ma, L.; Zhu, Y.; Ji, W. An investigation on responsible innovation in the emerging shared bicycle industry: Case study of a Chinese firm. J. Open Innov. Technol. Mark. Complex. 2019, 5, 42. [CrossRef]

69. Do, M.; Jung, H. The socio-economic benefits of sharing economy: Colleague-based carpooling service in Korea. J. Open Innov. Technol. Mark. Complex. 2018, 4, 40. [CrossRef] 
70. Yun, J.J.; Zhao, X.; Jung, K.; Yigitcanlar, T. The culture for open innovation dynamics. Sustainability 2020, 12, 5076. [CrossRef]

71. Yun, J.J.; Liu, Z. Micro-and macro-dynamics of open innovation with a quadruple-helix model. Sustainability 2019, 11, 3301. [CrossRef]

72. Niankara, I.; Muqattash, R.; Niankara, A.; Traoret, R.I. COVID-19 Vaccine Development in a Quadruple Helix Innovation System: Uncovering the Preferences of the Fourth Helix in the UAE. J. Open Innov. Technol. Mark. Complex. 2020, 6, 132. [CrossRef]

73. Roman, M.; Varga, H.; Cvijanovic, V.; Reid, A. Quadruple Helix Models for Sustainable Regional Innovation: Engaging and Facilitating Civil Society Participation. Economies 2020, 8, 48. [CrossRef]

74. Holmberg, S.; Rothstein, B.; Nasiritousi, N. Quality of government: What you get. Ann. Rev. Political Sci. 2009, 12, 135-161. [CrossRef]

75. Rothstein, B. The Quality of Government: Corruption, Social Trust, and Inequality in International Perspective; University of Chicago Press: Chicago, IL, USA, 2011.

Publisher's Note: MDPI stays neutral with regard to jurisdictional claims in published maps and institutional affiliations.

(C) 2020 by the authors. Licensee MDPI, Basel, Switzerland. This article is an open access article distributed under the terms and conditions of the Creative Commons Attribution (CC BY) license (http://creativecommons.org/licenses/by/4.0/). 